http://dx.doi.org/10.4314/gjl.v6i2.3

\title{
THE SYNTAX OF MULTI-WORD EXPRESSIONS IN YORULISH CODE-MIXING
}

\author{
MT Lamidi
}

\begin{abstract}
Scholars have discussed Yorulish (Yorùbá-English) code-switching/mixing from the perspectives of sociolinguistics, contact linguistics and pragmatics, among others; but the syntax-semantics aspect has not enjoyed much scholarly scrutiny, if any. Multi-word expressions (MWEs) are characterised by noncompositionality as they comprise two or more words, which have a unique meaning not traceable to any of the combined words. This study examines the syntactic behaviour of MWEs in Yorulish code-switched grammar, with an eye to the meaning before and after code-switching/mixing. The adopted theoretical framework is a combination of Myers-Scotton's Matrix Language Frame theory and Chomsky's Transformational Generative Grammar. Data were purposively sampled from standard dictionaries and textbooks on English and Yorùbá languages, and code-switched/mixed with words from the alternate language. The MWEs selected are idioms (from English and Yorùbá); phrasal verbs, phrasal-prepositional verbs and prepositional verbs (from English); and splitting verbs and serial verb constructions (from Yorùbá). The study suggests that switching is allowed when components of MWEs are relatively free as in English prepositional verbs, but barred when they are fixed as in Yorùbá splitting verbs and idioms. Nevertheless, apart from idioms where both English and Yorùbá substrates resist switching, the other Yorùbá MWEs are more impervious to switching than do those of English origin, which suggests that Yorùbá is the base language.
\end{abstract}

Keywords: Yorulish, code-mixing, multi-word expressions, Matrix Language Frame theory

\section{Introduction}

Yorulish is a term coined by Lamidi and Ajongolo (2001). It is a blend of Yorùbá and English, and refers to the combined substrates of Yorùbá-English codemixed/switched linguistic variety. Code-switching is described as a switch from one 
language to another in the course of speaking with respect to topic, tone, audience, situation, mood, etc. (Bentahila and Davies 1983). Code-mixing on the other hand is the mixture of words from languages in contact (Essien 1995). They are both referred to respectively as inter-sentential and intra-sentential code-switching (Muysken 2000). This study is based on intra-sentential code-switching, otherwise called code-mixing.

Multi-word expressions (MWEs) are words that are usually collocated everywhere they occur in sentences. Such expressions, which are found in different languages, include (but are not limited to) idioms (from English and Yorùbá), phrasal verbs, prepositional verbs, and phrasal-prepositional verbs (from English); and splitting verbs and serial verbs (from Yorùbá). This paper discusses all MWEs identified in the preceding sentence. The MWEs refer to combinations of a lexical verb and one or more words or particles. The particles are either adverbs or prepositions or both. When the particle is an adverb, the multi-word combination is a phrasal verb. When the particle is a preposition, the combination is a prepositional verb; and when both adverb and preposition particles co-occur with the verb, the combination is a phrasal-prepositional verb (Quirk and Greenbaum, 1979; Greenbaum and Nelson, 2002; van Gelderen, 2010). All these originate from the English language.

The splitting verbs and the serial verbs discussed here originate from Yorùbá language. Splitting verbs have the peculiar nature of either occurring alone or being split into two (Awobuluyi 1978), whereas serial verbs refer to a series of verbs that occur adjacent to one another in a structure (Lawal 1986). Regardless of the combination, the MWE constitutes a unit of meaning; it is not necessarily an aggregate of the meaning of the individual components. The combined words behave like a single verb. In this paper, the behaviour of MWE verbs in Yorulish code-switching is explored within the purview of Matrix Language Frame and Transformational Generative Grammar, a competence grammar. The paper looks at issues of compositionality, grammaticality and acceptability.

\section{Syntax-semantics interface in Yorulish Code-switching}

This eclectic study is being carried out from a combination of different theories and concepts. The first is Matrix Language Frame (MLF), propounded by Myers-Scotton. Myers-Scotton $(1993 \mathrm{~b}, 2002)$ has tried to formalise a psycholinguistic/grammatical theory of code-switching. She presents the Matrix Language Frame (MLF), which posits the occurrence of a main or base (or host) language and an embedded language in a code-switched grammar. The main language is said to donate most of the functional categories in a code-switched structure. She justifies this through the two twin concepts of (i) Morpheme Order Principle, in which case the order of the morpheme will be in 
the Matrix Language (ML) structure and (ii) System Morpheme principle, in which the system morphemes come from the host language.

The second is Chomsky's transformational generative grammar (TGG). Although TGG has many models, this paper will be concerned with the concept of competence, which runs through them all. Competence is the ideal native speaker/hearer's ability to use a language flawlessly. This study is located in this theory, since it is concerned with the acceptability and grammaticality of expressions. A sentence is grammatical if it obeys all the relevant rules guiding the formation of the sentence; otherwise, not. Borsley (1991) draws a line between grammaticality and acceptability. A structure that is grammatical may be acceptable or unacceptable. A structure that violates the rule(s) of grammar is unacceptable. When a structure is too long for the perceptive ability of an individual, it is considered unacceptable. In the same vein, a sentence that requires pen and paper analysis before it can be understood is also unacceptable. This study will be looking at structures in the context of the switching of codes from one to the other of the languages involved in code-switching. In this sense, the switch from one code to another is a major means of determining whether a structure is grammatical or acceptable. In other words, if a structure tolerates switching, the product of the switching will be grammatical and acceptable. If, however, a structure resists switching, the product of switching any of its components will be considered ungrammatical and unacceptable.

Of particular relevance to this study is the concept of head. The head is the most important word in a phrase. It is unique and obligatory in phrases. The head has been defined by many scholars (such as Jackendoff, 1977 and Chomsky, 1986); but we shall be guided by the definitions offered in Hoeksema (1990: 2):

(A) Semantic: The head of $\mathrm{A}$ is a hyperonym of A, i.e. when A denotes a set $X$, the example of A denotes a superset of $X$

(B) Distributional: The head of $\mathrm{X}$ is a part with the same distribution as $\mathrm{X}$.

(C) Morphosyntactic: The head is the locus of Inflection

(D) Technical: The head of $\mathrm{X}$ is the part, which determines the category of $\mathrm{X}$.

This study adopts these definitions as they determine the grammaticality and acceptability of elements under the scope of the head. The study focuses particularly on the implication of the technical and semantic definitions because they account for subcategorisation and semantic selection features.

While syntax deals with the arrangement of words in an expression, semantics deals with the meaning of such expressions. Regardless of the syntactic structure, words 
can occur freely or co-occur with other words regularly with constant meaning (collocation). One area of syntax-semantics interface is compositionality. "Compositionality refers to the degree to which the meaning of a MWE can be predicted by combining the meanings of its components" (Korkontzelos and Manandhar, 2009: 65). MWEs or collocated expressions are said to be compositional if each word contributes to the totality of the meaning of an expression. According to Carnie (2010: 22),

The hypothesis of compositionality holds that the syntactic tree is the road map for this semantic computation. That is, semantic composition applies precisely in the order specified by the hierarchical constituent structure. If two elements $\mathrm{x}$ and $\mathrm{y}$ form a constituent excluding $\mathrm{z}$, then the meaning of the $(\mathrm{x}, \mathrm{y})$ pair is computed before $\mathrm{z}$ is added into the mix.

This means that words participate structurally and semantically in the realization of the structure and meaning of expressions. Each word has a meaning and belongs to a syntactic category. So, when a word is removed from an expression, it leaves a gap in the structure and meaning of the expression. For instance, the expression, a young man, is compositional, referring to a male that has not matured. If we remove young, the meaning is reduced because the meaning of young has been left out in the overall interpretation.

Conversely, a structure is not compositional if we cannot identify the contribution of each of its component parts. In other words, all the words in the structure form a unit of meaning. In this sense, when a word is removed from the group, the initial meaning is disrupted or unrealised. Rather, we get a literal meaning or a nonsense meaning. The whole expression is listed in the lexicon as a unit of meaning. In the following example, for instance, if any word is taken away, the total meaning collapses. In eat humble pie, if we take away humble, the meaning changes and becomes compositional: eat pie. This is a literal translation. Sometimes, however, certain collocated expressions can be twisted or modified. This, however, makes the expression susceptible to literal translations or changes in meaning. For instance, look can be collocated with different particles or prepositions. Hence, we have look out (be vigilant/face), look in (look briefly) and look for (search for). Considering the different meanings indicated against each expression in the brackets, the first two belong to MWEs, the last does not. The expressions with deep/embedded meaning as opposed to those with literal meanings include idioms and metaphors. Regardless of the compositional status of MWEs, however, there is an internal unity orchestrated by the head and the complements in conformity with the rules of the language. If, for instance, a syntactic rule is broken, 
the expression becomes unacceptable. Hence, MWEs also have internal syntactic rules guiding their components.

Given the fact that a set of words also with unified meaning allows splits or interchange with particles and some expressions have a unified meaning for a number of words without switches, this study investigates the phenomenon of code-mixing in both cases, to see the speech patterns and how mixing occurs as well as how meaning is affected by the phenomenon. With MLF theory in the background, and Competence and Compositionality at the forefront, the paper is expected to distinguish between literal and idiomatic expressions through the phenomenon of code-mixing. This study looks at the syntax-semantics relationship of words within MWEs. We examine how MWEs behave when they are code-mixed and identify what makes them grammatical or ungrammatical.

\section{Previous studies}

Several studies in code-switching have been carried out on different aspects of the phenomena. These include the motivation for switching between languages (MyersScotton 1993a, Auer 1998), classification of switches (Muysken 2000), psycholinguistic perspectives on code-switching (Green 1998, Treffers-Daller 1998, Toribio 2001), the grammatical basis of code-switching as well as constraints that apply to each pair of mixed languages (Poplack 1980, Bentahila and Davies 1983, Myers-Scotton 1993b, 2000, MacSwan 2000, van Gelderen and MacSwan 2008), bilingual children's code-switching (Treffers-Daller 1998, Hoeksema 1990, Carnie 2010, Cantone \& Müller 2008, Liceras et al. 2008) and code-switching in e-mails (Hinrichs 2006). Many studies have also been carried out on pairs of languages, but very few exist on codeswitching involving more than two languages (Ogechi 2002, Kyuchukov 2002) and, still less are studies on written code-switching especially on virtual speech communities (Montes-Alcalá, 2007; Lamidi, 2013).

Studies have also been conducted on pairs of languages such as Spanish-English (Pfaff 1979; Poplack 1980, Sankoff and Poplack 1981, Franco and Solorio 2007); Arabic-French (Bentahila and Davies 1983), American Sign Language- English (Lucas and Valli, 1992), English-Creole (Hinrichs 2006), Swahili-English (Myers-Scotton 1993 a\&b, 2002), Turkish-Dutch (Backus and Eversteijni 2002) and Yorùbá-English (Banjo 1983, Goke-Pariola 1983, Lamidi 2013).

In Yorùbá- English CS, the studies have been largely on sociolinguistics (see Banjo 1983, 1996; Goke-Pariola, 1983; Bamiro, 2006, Ayeomoni, 2006; and Babalola \& Taiwo 2009) and on morphology and syntax (see Lamidi \&Ajongolo, 2001; Lamidi 2003, 2004, 2008 a\&b and 2013). Lamidi and Ajongolo (2001) discuss the morphosyn- 
tactic structure of heads in Yorulish code-switched words. The study identifies morphemes from the Yorùbá substrate as heads of their respective code-switched words, thus confirming Myers-Scotton's MLF theory. The same conclusion was reached in Lamidi (2004) which looks at the scopal authority of heads in the Yorùbá-English codemixed grammar. According to the study, functional heads such as complementiser and determiner regulate the structure of a phrase; lexical heads determine the type of word that follows them. Both head types subcategorise or determine the structure of their complements (which fall within their scope). The study concludes that Yorùbá is the Matrix language. These two papers are relevant to the current effort, which also discusses Yorùbá-English code-mixing. It is important to emphasise that the current study involves syntax-semantics interface, which the earlier study did not consider. The study will benefit from the concept of head and scopal authority within phrases. It will explore grammaticality and acceptability from the perspective of subcategorisation and s-selection.

Another relevant study is Lamidi (2008a). It investigates hybrid verbs in Yorùbá-English code-mixing. The study identifies clean verbs, which exhibit the normal features of verbs from English and Yorùbá from their respective source substrates, and hybrid verbs, which have idiosyncratic features different from what obtains in their respective source languages. Lamidi (2004) is principally on how a head regulates the items that are dependent on it in its scope and Lamidi (2008a) is principally on the nature of lexical verbs. However, the current study is on multi-word expressions; and, to my knowledge, no study so far has discussed Yorùbá-English code-mixing in multiword expressions, least of all, its syntax-semantics interface, grammaticality and acceptability, which are the foci of the current paper. Therefore, the current study pushes forward the discussion in Lamidi (2008a) as it explores the behaviour of a variety of code-switched MWE structures in different contexts.

\section{Data Collection}

Data comprising MWEs were collected from the Oxford Advanced Learners' Dictionary of English (for English language) and Awobuluyi (1978) (for Yorùbá language). Additional data were also generated through introspection by the researcher, who has native speaker competence in Yorùbá. The data collected were phrasal verbs, prepositional verbs and phrasal prepositional verbs (from English); serial verb constructions, splitting verbs (from Yorùbá); and idioms (English and Yorùbá). Of all these, those MWEs that are relatively in common use among the Nigerian populace were purposively selected for code-mixing with the other language. The data from English were code-mixed with words from Yorùbá while data from Yorùbá were code- 
mixed with words from English. Idioms from English were code-mixed with words from Yorùbá while idioms from Yorùbá were code-mixed with words from English. The products of the code-mixing processes were analysed for grammaticality and acceptability. In the data that follows, English expressions are presented in italic typeface while Yorùbá expressions have normal typeface. This is to distinguish the two codes in each structure. The MWEs are presented in bold print.

\section{Phrasal Verbs}

A phrasal verb consists of a verb and an adverb, both forming a unit of meaning. However, in English grammar, because the adverb 'no longer always expresses place or direction' (van Gelderen, 2010: 91), it is called a particle in this context. Quirk and Greenbaum (1979) have classified phrasal verbs into two: intransitive phrasal verbs and transitive phrasal verbs. In Yorulish grammar, the phrasal verb is contributed by the English substrate.

\subsection{Intransitive Phrasal Verbs}

Transitive phrasal verbs take objects while intransitive phrasal verbs do not. Here are some examples of intransitive phrasal verbs from the Yorulish grammar:
$\begin{array}{llll}\text { 1a. Plane yẹ } & \text { ti } & \text { take off. } \\ \text { Plane the } & \text { ASP taken off }\end{array}$
'The plane has taken off.'
b. Olú turn up ní meeting yẹn unexpectedly.
Olú turned up at meeting that unexpectedly

'Olu turned up at the meeting unexpectedly.'
c. Sé ó ń catch on?
Q 3SG CONT catch on

'Does s/he catch on?'

$\begin{array}{cccl}\text { d. Man } & \text { yẹn } & \text { break down } & \text { lójìjì. } \\ \text { Man } & \text { that } & \text { break down } & \text { suddenly }\end{array}$

'That man broke down suddenly.' 


\section{e. Ó ń play around}

\section{3sg CONT play around}

'He's playing around.'

The first observation about these sentences is that the system morphemes are usually from the Yorùbá substrate. Normally, Yorùbá verbs are always not inflected for tense and agreement. This lack of inflection also occurs on the first words in the phrasal verbs. In the foregoing examples, for instance, the tense and agreement features of English are replaced by the non-inflected form of Yorùbá, even on English verbs. In addition, function words such as perfective and progressive aspect markers (ti and ń respectively) are in Yorùbá. The clitic (ó), the determiner (yẹn) and the question marker (șé) are all donated by the Yorùbá substrate. In addition, following the Morpheme Order Principle, we can see that the word order favoured is that of Yorùbá. For instance, meeting yẹn has the structure $\mathrm{N}+$ Determiner, whereas the reverse, Determiner $+\mathrm{N}$, is the structure permitted in English. English polar questions involve the use of auxiliary-NP inversion, but the polar question in (1c) uses a question marker that is attached sentence-initially. These features are peculiar to the Yorùbá substrate. In these and subsequent examples in this paper, these are the overriding features. Hence, we confirm that Yorùbá is the host language (following the ideas of Myers-Scotton, 1993) in the codeswitched grammar under discussion as observed in previous literature. ${ }^{1}$

Considering the examples from the perspective of MWEs, the phrasal verbs, as a unit, do not have objects. Rather, they are either left bare (1a, c \& e) or followed by adverbials ( $1 \mathrm{~b} \& \mathrm{~d})$. In all the examples, switching of other elements in the sentences are permitted but switching items within phrasal verbs to Yorùbá is not permitted. Otherwise, the sentence will be barred as in the following:
2a. *Olú take kúrò
b. * Olú turn lókè ni meeting yẹn unexpectedly.
c. *Man yẹn kán off lójìjì
d. *Șé o ń mú on?
e. $\quad *$ O ń play àyíká

\footnotetext{
${ }^{1}$ To avoid repetitions of the same ideas, the status of Yorùbá as the host language in the codeswitched grammar will not be pursued further in other examples below. Readers may wish to read up on the subject in Banjo (1983), Goke-Pariola, (1983) and Bamiro (2006), among others.
} 
As examples (2a-e) show, switching of this class of phrasal verbs into Yorùbá causes ungrammaticality and is therefore barred. What accounts for the ungrammaticality? We can trace this to the heads of the phrasal verbs: take, turn, kán, mú and play. The heads, following the ideas of Lamidi (2004), have scope over the particles and determine the type of word that follows them and whether such words or particles can be switched from English to Yorùbá without negative repercussions. As observed in examples (2a-e), switching is not allowed between the head and the particle in the intransitive phrasal verb. However, a phrase of Yorùbá origin can come before and/or after the phrasal verb as seen in (1a-e). Hence, the intransitive phrasal verb can be seen as an embedded island (Myers-Scotton, 1993b). The structures also fail on the pedestal of acceptability. This is because the meanings do not tally with the intended ones depicted in the translations.

By invoking Hoeksema's descriptions of head above, we can identify the words take, turn, catch, break and play as heads in their respective phrasal verbs in (1a-e). The heads have semantic content, which determines the meaning of the respective structures. They occur at the beginning of the expressions (Distributional content), they collocate with the particles and earn the structure its name (Technical content) and they are changeable, depending on agreement or tense factors: he turned up; she turns up (Morphosyntactic content). Hence, in this and subsequent examples from the English substrate, the first word in the MWE is the head.

This conclusion appears to contradict Williams' (1982) Right Hand Head Rule, which states that the inflection to the head occurs at the right-hand side of the word. To accommodate this claim, we shall posit that the inflections occur to the right-hand side of the word which is within another structure. However, since this is beyond the scope of this paper, and it will no longer be pursued here.

\subsection{Transitive phrasal verbs}

As in lexical verbs, the transitive phrasal verbs require an object. This fact is exemplified in the following:

3a. Wộn switch on iná sitting room

they switch on light sitting room

'They switched on the light in the sitting room.'

b. A set up committee tuntun

we set up committee new

'We set up a new committee.' 
c. A ti call off strike yẹn We ASP call off strike that

'We have called off that strike.'

d. Ó fẹe find out nìkan tí wộn ń plan 3sg want find out what that they CONT plan

'S/he wants to find out what they are planning.'
e. Òu l'ó bring over àwọn boys yẹn. 3sg FOC bring over PL boys that 'It was s/he that brought over those boys.'

In examples (3a-e), each of the sentences may not be complete if the noun phrases adjoining the phrasal verbs are removed. Hence, the phrasal verbs are transitive. The phrasal verbs in these examples also reject switching within the components of the phrasal verbs. However, they may allow Yorùbá words to come in-between them. In this sense, we cannot tag them as embedded language (EL) like their intransitive counterparts. Here are examples; they have the respective translations in (3) above.

$\begin{array}{cl}\text { 4a. } & \text { Wọ́n switch iná sitting room on. } \\ \text { b. } & \text { A set committee tuntun up. } \\ \text { c. A ti call strike yẹn off. } \\ \text { d. Ó fẹ find nǹkan ti wộn ń plan out. } \\ \text { e. Òun l'ó bring àwọn boys yẹn over. }\end{array}$

Again, as the examples from both types of phrasal verbs show, switching is permitted within the sentences containing the multi-word, but the phrasal verbs are not switched into Yorùbá, as exemplified below:
5a. *Wộn yí on iná sitting room.
b. *A set òkè committee tuntun.
c. $\quad *$ A ti pè off strike yẹn.
d. *Ó fẹ́ find ìta nìkan ti wớn ń plan.
e. *òn l'ó mú over àwọn boys yẹn 
Examples (5a-e) demonstrate that switching is barred for this class of phrasal verbs. The question is: what is the nature of switching in these constructions? Consider the following additional examples with variations in switch patterns:
6a. Olú give up
'Olu gave up.'
b. *Olú give òkè
c. *Olúfún up

\section{7a. Șadé give in \\ 'Sade gave in.' \\ b. *Șadé give inú \\ c. *Sadé fün in}

\section{8a. Àwọn terrorists blow up motor yẹn. \\ b. Àwọn terrorists blow motor yẹn up. \\ 'The terrorists blew up the vehicle.' \\ c. *Àwọn terrorist fọ́ motor yẹn up. \\ d. *Àwọn terrorists blow motor yẹn sókè.}

In these sentences, the components of the phrasal verbs are switched either into Yorùbá or English (6b\&c, $7 b \& c, 8 c \& d)$. While the first item is switched into Yorùbá in $(6 \& 7 \mathrm{c})$ the second word is switched into Yorùbá in $(6 \& 7 b)$. The position is reversed for $(8 c \& d)$, respectively. In all cases, the result is ungrammatical and unacceptable.

Nevertheless, there are some good cases, which confirms that individual heads also determine the grammaticality and acceptability of the code-switched expressions:

9a. Ó ń act fún president

'He's acting for the president.'

b. Wọn adhere to/abide by the rule

c. Wộn adhere sí/abide pẹ̀lú rule yẹn

'They abided by/adhered to that rule.'

In these examples, act for becomes act fún, adhere to/adhere bybecomes adhere sí/abide pẹ̀lú. Instances of these are not many in our data.

Hence, within phrasal verbs, switching components of the multi-word verbs into Yorùbá is usually disallowed as evidenced in the bad cases. The first reason given above is about the head determining what comes after it. This is a syntactic reason. The second possible reason, a semantic reason, is that the multi-word is a unified phrase 
with a recurrent meaning. If switching is allowed in any of its components, the meaning may be lost or distorted. This is a confirmation that the phrasal verb is a form of idiom, as widely observed in the literature.

\section{Prepositional verbs}

Prepositional verbs contain a verb and a preposition; hence the name 'prepositional verbs'. However, if we follow van Gelderen's (2010) ideas, the preposition may be seen as a particle. Either way, it does not affect the analysis here; hence 'preposition' is adopted. In the following examples, there are different patterns regarding switching. 6.1 Prepositional verbs that reject switching

In this type of structure, switching is barred within components of a prepositional verb, though other constituents within the sentence in which the prepositional verb occurs may be switched. Consider the following; the prepositional verbs are typed in bold:
10a. Adé look after
bàbá è.
Ade looked after father his
'Ade looked after his father.'
b. *Adé wo after bàbá è
c. *Adé look léyìn bàbá è
11a. Excitement wọn ti die down
Excitement their ASP die down
'Their excitement has died down.'
12.a. *Excitement
wọn ti kú down
b. *Excitement
wọn ti die sílẹ
c. *Excitement
wọn ti kú sílẹ̀
13a. Wọ́n put off decision wọn
They put off decision their
'They put off their decision.'

b. *Wọ́n gbé decision wọn off

c. *Wọ́n put decision wọn kúrò 


\section{4a. Wọ́n stand up nígbà t'ó dé}

They stand up when that: he arrive

'They stood up when he arrived.'

b. *Wộn stand dúró nígbà tó arrive/when he arrived

c. *Wọ́n dìde up nígbà tó arrive/when he arrived

d. Wộn dìde dúró when he arrived/nígbà tó arrive

15a. Discussion go on fún ìgbà pípẹ́

Discussion go on for time late

'The discussion went on for a long time.'

b. *Discussion lo on fún ìgbà pípẹ́

c. *Discussion went ṣíwájú for a long time

In these examples, the first word in each prepositional verb is the head. The switching of either part of the prepositional verb is not allowed, as the starred (b \&c) examples in all the examples show. Note, however, that in (14d), both components of the prepositional verbs are switched into Yorùbá. This is possible because the two words collocate in Yorùbá but a Yorùbá word and an English word that jointly form a prepositional verb may not collocate.

\subsection{Preposition deletion pattern}

Another pattern is that in which the English preposition is elided in the codeswitched grammar, leaving only the lexical verb. Notice also that this elision does not affect the original meaning of the multi-word verb. This is another method of avoiding ungrammaticality in the code-switched grammar. Consider the example below.

\section{6a. Ó approve of your behaviour}

3 sg approve of your behaviour

'S/he approves of your behaviour.'

b. Ó approve - behaviour ẹ

c. Ó approve (?of) behaviour ẹ

In this example, the second part of the prepositional verb (of) occurs in (16a) in what Myers-Scotton (1993b) calls embedded language (EL) (a structure that is wholly of a particular substrate in a code-switched language and thus maintaining the rules of that language only). It is deleted in (16b), following the rules of the matrix language (in this case, Yorùbá). In (16c), however, the structure is of doubtful acceptability. Further data may be required to establish its status. 


\subsection{Prepositional verbs that permit switching}

The third pattern is that in which the preposition is switched from English into Yorùbá. Again, the original meaning of the multi-word prepositional verb is not affected. This is exemplified in (17-22).

17a. Principal call fún water

'The principal called for water.'

b. * Principal call for omi

c. Heavy smoking ń lead to/sí cancer

'Heavy smoking leads to cancer.'

18a. Ó blame accident yẹn on the driver (embedded language)

'She/He blamed the accident on the driver.'

b. Ó blame accident yẹn l'órí driver.

19a. Ó lè order drink fún mi

'He/she can order a drink for me.'

b. Ó lè order drink for me (embedded language)

20a. Ó explain fún mi

'He/She explained to me.'

b. Ó explain to me (embedded language)

21a. Ó forgive mi fún rude remarks mi

'He/She forgave me for my rude remarks'

b. Ó dárí jì mí for my rude remarks (embedded language)

22a. Ó congratulate è̀ fún convocation ẹ̀

'She/he congratulated him/her on his/her convocation'

b. Wọ́n abide pẹ̀lú terms wa

'They abided with our terms'

c. Ó refer sí article yẹn

'He/she referred to that article.'

In these examples, the prepositional verbs are call for, lead to, blame on, order [something] for, explain to, forgive for and congratulate on. These are switched respectively, to call fún, lead sí, blame lórí, order fún, explain fún, forgive fún and 
congratulate fún. The possibility of switching here ensued from the fact that the lexical verbs have the major meaning while the preposition is merely playing a supportive role by just linking the verb to the NP that serves as the complement. Again, switches are allowed only on the second element of the prepositional verbs without any negative repercussion. However, when the second element of the MWE is in English, an embedded language must be formed with this second element as in (18a, 19b, 20b, 21b) to avoid ungrammaticality. Finally, the structure is grammatical if the prepositional verb occurs with a switch (as in 17a, 18b, 20a, 21a \& 22), with an intervening element (18, $19,21 \& 22 a)$ and along with embedded language (18a, 19b, 20b \& 21b), which are all good cases.

\section{Phrasal-Prepositional Verbs}

These are verbs followed by two particles: an adverb and a preposition (in that order). Just like what obtains under prepositional verbs, some prepositional phrasal verbs allow switching of their components, but some do not as in the following examples:

$\begin{array}{rlll}\text { 23a. Wọ́n ń } & \text { look down on àwọn } & \text { neighbours wọn } \\ \text { They } & \text { CONT } & \text { look down on PL } & \text { neighbours their }\end{array}$

'They are looking down on their neighbours/They look down on their neighbours.'

b. O walk out on me!

'You walked out on me!'

There is also a pattern where switching is allowed. However, only the last component of the MWE can be switched.

$\begin{array}{llll}\text { 24a. Wọ́n put è̀ up fún eviction. } & \\ \text { They put } & \text { 3sg up for eviction } \\ \text { 'They put her/him up for eviction.' }\end{array}$

b. Ó put problem yẹn down sí inexperience.

3 sg put problem that down to inexperience

'She/He put the problem down to inexperience.'

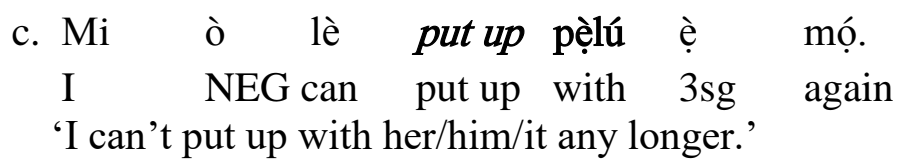




\section{d. Biola come up pẹ̀lú new ideas/theory tuntun.}

Biola come up with new ideas/theory new

'Biola came up with new ideas/a new theory.'

In comparison with what happened in the discussion on prepositional verbs, the preposition is observed to be the only item that switches to Yorùbá wherever switching is permitted. This means that the lexical verb and the adverbial particle are not switched. Again, while some phrasal-prepositional verbs allow switching, some do not. This implies that there are different levels of non-compositionality among the MWEs. The more compositional an expression is, the more it permits switches; the less compositional it is, the less it permits switching.

\section{Splitting Verbs}

Splitting verbs are contributed to the code-switched structure by the Yorùbá substrate. They refer to verbs that have two parts each of which cannot occur independently and be meaningful. Hence, they normally co-occur either as a combined word or as splits in a sentence. According to Awobuluyi (1978: 53), "when used with an object, each verb in this class is always split into two halves, and their object is inserted between them... Many of them have idiomatic meanings." Examples include bàjẹ 'spoil', gbàgbọ́ 'believe' and túká 'disperse.'

When they occur together as a word, splitting verbs can be switched wholly into English as in the following examples:

\section{5a. Computer yìi ti bàjệ/crash}

'This computer has got spoilt/crashed'

b. Àwọn students ti túká/disperse

'Students have dispersed'

c. Ó gbàgbọ́/believe pé man yẹn try

'She/He believed that that man tried.'

However, when they are split, neither part of a splitting verb may be switched into English, but rather English nouns/words can come in between them. 


$$
\begin{aligned}
& \text { 26a.Ó ba bikemi jẹ́ } \\
& \text { 3sg - bike my - }
\end{aligned}
$$
27a. Ọlộpàá tú àwọn rioters yẹn ká
Police loosen pl rioters those around
'The police dispersed those rioters'
b. *ọlọpàá loosen àwọn rioters ká
28a. Farmer yẹn fọ́n oranges yẹn ká
Farmer that spray oranges those around
'The farmer threw those oranges about/around.'
b. *Farmer yẹn spray grains yẹn ká

29a. Adé tún bike mi șe

Adé again bike my do

'Adé repaired my bike.'

b.*Ade again bike mi șe

30a. Bíolá bá man yẹn wí
Biola with man that talk
'Biola rebuked that man.'
b. *Biola with man yẹn wí
31a. Teacher rẹ student ẹ jẹ
Teacher cut student his eat
'The teacher cheated his student.'
b. * Teacher cut student è jẹ

32a. Àwọn church members gba pastor wọn gbọ́

Àwọn church members accept pastor their hear

'The church members believed their pastor.'

b. *Àwọn church members accept pastor wọn gbọ́ 
33a. Pastor be àwọn brethren wò

Pastor check pl brethren look

'Pastor visited the brethren.'

b. *Pastor check àwọn brethren wò (with the interpretation of 33a)

34a. Boy kan tan friend ẹ̀ jẹ

Boy certain trick friend 3 sg eat

'A certain boy tricked his friend.'

b. *Boy kán tan girlfriend è̀ eat

35a. Chameleon pa colour è̀ dà

Chameleon paint colour 3sg -

'The chameleon changed its colour.'

b.*Chameleon paint colour ẹ dà

36a. Bag yẹn kò bá shoes mu

Bag that not with shoes parallel

'That bag does not match the shoes'

b. *Așo yẹn kò bá ara match

'The clothes did not match his body.'

37a. Títí di pillar mú

Títí hold pillar take/catch

'Títí held on to the pillar'

b. *Títí hold pillar mú
38a. Man yẹn
pa second wife è̀
tì.
Man that
second wife his
'That man abandoned his second wife.'
b. * Man yẹn pa second wife è̀ aside. 
39a. Attitude yẹn bu master wá kù

Attitude that cut master our remain

'That attitude ridiculed our master.'

b. *Attitude yẹn cut master wá kù

40a. Wọ́n pa ideas wọn pọ.

They combine ideas $3 \mathrm{pl}$ together

'They combined their ideas.'

b. *Wọ́n pa ideas wọn together.

In these examples, it is difficult to find meanings to parts of the splitting verbs. Hence, '-' is often used instead in some cases. In other cases, meaning that approximates to each half of the splitting verb is presented. The first part of the splitting verb seems to have some sort of meaning which approximates partially to the intended meaning. Throughout these examples, we can see that the splitting verbs are impervious to switching. However, splitting verbs generally allow English words to come in-between them as demonstrated in all the examples presented above.

So, what accounts for the ungrammaticality of the other examples? The major reason for the unacceptability of switching is that each part of the splitting verb is meaningless without the other part. Although each of the parts may be meaningful in some contexts as an individual word, such meanings may not be sustainable when the words are switched into English. This explains why certain halves of the splitting verbs are translatable while the other parts are not.

We conclude, therefore, that splitting verbs maintain their identity in codemixed structures. Switches of either part of the splitting verb may render the expressions ungrammatical and unacceptable.

\section{Serial Verb Constructions}

Serial verb constructions (SVCs) are a series of two or more verb roots that cooccur but are not compounded in a sentence (Payne, 1997: 307). However, the tense is often reflected on the first verb (Lawal, 1989; Collins, 1997). The Yorùbá part of the code-switched grammar contributes the SVC structure and English words are switched with them. Again, this confirms the Yorùbá substrate as the host language. Here are some examples: (41-46) are borrowed from Lamidi, (2003):

\begin{tabular}{|c|c|c|c|}
\hline 41. Mo & fẹ́ & lọ & pray. \\
\hline I & want & go & pray \\
\hline
\end{tabular}


42. Kíni o fi register?

What you use register

'What did you use to register?'

43. Mo fẹ $\quad$ record ẹ̀.

I want record it

'I want to record it.'

44. Òjó grumble wá síbí.

Òjó grumble come here

'Òjó grumbled as he came here.'

45. O se rice jẹ.

You cook:pst rice eat:pst

'You cooked rice and ate it.'

46. Sọojà plan coup dáràn.

Soldier plan coup get:into:trouble

'A soldier planned a coup and got into trouble.'

We can subject these examples to different switch patterns and see how the SVCs behave.

47a. *Mo fẹe go pray.
b. *Mo like lo pray.
c. *Kí ni o use register?
d. *Mo like record $(V)$ ẹ́.
e. *Òjó grumble come síbí (Lamidi, 2003: 315)

From the good examples, we can see that switches are permitted among components of SVC. From (41-43), the first word in the SVC is in Yorùbá, while the second/third word is in English. In (44 \& 46) the second word of the SVC is Yorùbá; and in (45), the SVC is purely in Yorùbá. However, in the bad examples (47a-e), it is shown that it is not every component of the SVC that can be switched; the switches are peculiar to each SVC structure. The ungrammaticality shows that those components of the SVCs 
that were switched made the structures ill-formed. Most especially, all the components of the SVC may not be switched (as in 47c-e).

\section{Idioms}

An idiom is a combination of words with a figurative meaning. Idiomatic expressions can be words, phrases, clauses or sentences. Idioms have a unique meaning, which cannot be pieced together (following the concept of compositionality) from the meaning of individual words in an expression. Rather, the expression has only one unified meaning. In English and Yorùbá (as well as other natural languages), idioms and metaphors have a unified meaning that cannot be deduced from the surface structure of individual words. Consider the following code-switched examples:

48a. He kicked the bucket. 'He died.'

b. Ó kick bucket náà (literal translation results: He kicked the bucket.')

c. Ó ta bucket nípàá 'He kicked a (particular) bucket.'

49a. He is pulling your leg 'He is joking with you.'

b. Ó ń pull leg/ẹsẹ ẹ (literal translation: He's pulling your leg.)

50a. Lead a dog's life 'live an unhappy life.'

b. Eat humble pie 'show remorse.'

c. Throw in the towel 'surrender.'

These idioms are of English language origin. As they are, they may permit switching (as in 49b), but at the cost of the intended meaning. In (48b\&c), the meanings of the expressions are literal. Both expressions refer to a particular bucket that an individual kicked or a leg that is pulled. This is different from the intended meaning of someone's death (48a) and joking (49a). Hence, English idioms do not allow switching, if they must maintain their meaning.

Consider the following Yorùbá idioms.

51a. Ó ta téru nípàá 'He died'

b. *Ó kick téru

3sg kick white-cloth 
52a. Gbogbo attempts yẹn fi orí șánpọon

All attempts that use head -

'All the attempts failed.'

b. *Gbogbo attempts yẹn fi head șánpọnn

\section{3a. Àwọn workers yẹ leader wọn ní sáà/*period \\ Pl workers dislodge leader them at period \\ 'Workers disgraced/lowered the status of their leader.' \\ b. *Àwọn workers remove leader wọn from sáà.}

In these examples, the idioms of Yorùbá origin resist switching. Apart from the fact that switching makes the expression unacceptable, it is not amenable to literal translations. So, if any word is changed, the meaning of the expression collapses.

\section{Conclusions}

Having gone through the analyses of different MWEs, we have come to the following conclusions. Switching in MWEs is effected through scopal authority and semantic selection. In scopal authority, the heads subcategorise the particles (if required), determine the kind of particles/words that should follow them and the possibility of switching them to the other language (as we find in 5 and other sections). The first word in a MWE serves as the head which determines whether the next or subsequent word will be switched. Semantic selection determines the logical form or meaning of an expression before and after switching. When switches occur, the meaning may become literal (as in idioms) or remain intact (as in other cases).

Two patterns of switching are found in Yorulish MWEs: (a) Total rejection of switching and (b) partial rejection of switching. While splitting verbs and idioms (especially from Yorùbá) (sections $8 \& 10$ ) totally reject switching of their components into the other substrate language, phrasal verbs (section 5), prepositional verbs (section 6), phrasal-prepositional verbs (section 7) and serial verbs (section 9) allow switching in some cases but reject it in others.

This means that there is a hierarchy, starting from the most impervious to the least impervious to switching. The reason for the rejection of switching can be traced to the non-compositional nature of the expressions that reject switching and the flexibility in the composition of those expressions that partially tolerate switching. Hence, we can observe levels of compositionality between two opposites. Those that are impervious to switching are non-compositional, while those that allow mixing are partially 
compositional, mixing/switching being more difficult as expressions become more non-compositional.

Finally, although both English and Yorùbá are similar in their sentence typology (they have Subject Verb Object word order), the order of words in each code-mixed structure usually conforms to the pattern in Yorùbá (as discussed in section 5.1). In the few cases where they do not conform, they are embedded language. This confirms that Yorùbá is the matrix language in Yorulish. 


\section{References}

Auer, Peter (ed.), 1998. Code Switching in Conversation, Language Interaction and Identity London/New York: Routledge.

Awobuluyi, Oladele, 1978. Essentials of Yoruba Grammar. Ibadan: Oxford University Press. Ayeomoni, M. O., 2006. 'Code-switching and Code-mixing: Style of Language use in Childhood in Yoruba Speech Community', Nordic Journal of African Studies, 15(1), 90-99.

Babalola, E. T. and Taiwo, R., 2009. Itupale Online Journal of African Studies, I: 1-26.

Backus, A, and Eversteijni, N., 2002. 'Pragmatic Functions and their Outcomes: Language Choice, Code-Switching and Non-Switching' Actas/Proceedings II Simposio Interacional Bilinguismo, pp 1393 - 1410 September 8, 2009 accessed from http://webs.uvigo.es/ssl/actas2002/07/02.\%20Ad\%20Backus.pdf.

Bamiro, Edmund O., 2006. 'The Politics of Code Switching: English vs Nigerian Languages.' World Englishes 25(1): 3-25.

Banjo, Ayo, 1983. 'Aspects of Yorùbá/English Language Mixing', Journal of Nigerian Languages (1):17-26.

Banjo, Ayo, 1996. Making A Virtue of Necessity: An Overview of the English Language in Nigeria. Ibadan: University Press PLC.

Bentahila, A. and Davies, E. I., 1983. 'The Syntax of Arabic-French Code-Mixing', Lingua: 59: 302-330.

Borsley, R. D., 1991. Syntactic Theory: A Unified Approach. London: Edward Arnold.

Bullock, Barbara E. and Toribio, Almeida Jacqueline (Eds.), 2009. The Cambridge Handbook of Linguistic Code-switching. Cambridge: Cambridge University Press.

Cantone, K F. \& Müller, N., 2008. 'Un nase or unanase? What gender marking within switched DPs reveals about the architecture of the bilingual language faculty', Lingua 111: 810826.

Carnie, Andrew, 2010. Constituent Structure Oxford: Oxford University Press.

Collins, Chris, 1997. 'Argument Sharing in Serial Verb Construction', Linguistic Inquiry 28(3): 461-497.

Chomsky, N., 1965. Aspect of the Theory of Syntax, Massachusetts: MIT Press

Chomsky, N., 1986. Barriers, Massachusetts: MIT Press.

Goke-Pariola, Abiodun, 1983. 'Code-mixing among Yoruba-English bilinguals', Anthropological Linguistics 25: 39-46.

Essien, O., 1995. 'The English Language and Code-Mixing: A Case Study of the Phenomenon in Ibibio.' In Ayo Bamgbose, Ayo Banjo and Andrew Thomas (Eds.) New Englishes: A West African Perspective, Ibadan: Mosuro, 284-299pp. 
Franco, J. C. and Solorio, T., 2007. 'Baby Steps Towards Building a Spanglish Language Model'. Retrieved February 7, 2007 from http://www.cs.utepo.edu/vladik/2007/tro705.pdf.

Green, D. W., 1998. 'Mental Control of the Bilingual Lexico-Semantic System', Bilingualism: Language and Cognition 1: 67-81.

Greenbaum, Sidney \& Nelson, Gerald, 2002. An Introduction to English Grammar, 2nd edn. London: Longman.

Hinrichs, L., 2006. Codeswitching on the Web: English and Jamaican Creole in E-mail Communication. (Pragmatics and Beyond 147.) Amsterdam, Philadelphia: Benjamins.

Hoeksema, Jack, 1990. 'The Head Parameter in Morphology and Syntax' Paper presented at Max Planck Institute of For Psycholinguistics in Nijmegen.

Jackendoff, Ray, 1977. X Syntax: A Study of Phrase Structure. Massachusetts: MIT Press

Korkontzelos, Ioannis \& Manandhar, Suresh, 2009. 'Detecting Compositionality in MultiWord Expressions,' Proceedings of the ACL-IJCNLP 2009 Conference Short Papers, pp 65-68.

Kyuchukov, Hristo, 2002. 'Code-Switching among Trilingual Turkish-Speaking Roma Children in Bulgaria,' Psychology of Language and Communication 6(1): 75-84.

Lamidi, M. T., 2003. The Head Parameter and Grammaticality in Yoruba-English CodeSwitching among Undergraduates in Selected Nigerian Universities, PhD Thesis, University of Ibadan.

Lamidi, M. T.,2004. 'Scopal Authority of Heads in Yoruba English Switching', Nordic Journal of African Studies 13 (1): 76-94 www.njas.helsinki.fi.

Lamidi, M. T., 2008a. 'Hybrid Verbs in Yorùbá-English Code-Mixing', Languages in Contrast 8 (2): 161-180.

Lamidi, M. T., 2008b. 'Pronoun Choice and Grammaticality in Yorùbá-English Code-Switching', Suvremena Lingvistica 66 (2): 223-241.

Lamidi, M. T., 2013. 'Feature Checking in Yoruba-English Code-Switching' in Wale Adegbite, Ayo Ogunsiji and Oye Taiwo (Eds.) Linguistics and the Glocalisation of African Languages for Sustainable Development. Ibadan: Universal Akada Books Nigeria Limited; pp311-330.

Lamidi, M. T. \& Ajongolo, T. O., 2001. 'The Head Parameter in Yorulish Morphology', Ihafa: A Journal of African Studies IV (1): 84-92.

Lawal, Adenike S.,1989. 'The Classification of Yoruba Serial Verb Constructions', Journal of West African Languages XIX: 3-14.

Liceras, J. M., Fuertes, R. F., Perales S., Perez-Tattam R.M, \& Spradlin, K. T., 2008. 'Gender and gender agreement in Bilingual native and non-native grammars: A View from child and adult functional-Lexical mixings', Lingua 118: 827-851.

Lucas, C. and C. Valli, 1992. Language Contact in the American Deaf Community. San Diego: Academy Press. 
MacSwan, J., 2000. 'The Architecture of the Bilingual language faculty: evidence from intrasentential code switching', Bilingualism: Language and Cognition 3 (1): 37-54.

Montes-Alcalá, Cecilia, 2007. 'Blogging in Two Languages: Code-Switching in Bilingual Blogs' Selected Proceedings of the Third Workshop on Spanish Sociolinguistics, (ed.) Jonathan Holmquist et al., 162-170. Somerville, MA: Cascadilla Proceedings Project; pp 162-170.

Muysken, P., 2000. Bilingual Speech: A Typology of Code-Mixing. Cambridge: Cambridge University Press.

Myers-Scotton, C., 1993a. Social Motivations for Code-switching. Oxford: Clarendon Press.

Myers-Scotton, C., 1993b. Duelling Languages: Grammatical Structure in Code-Mixing. Oxford: Clarendon Press.

Myers-Scotton, C., 2002. Contact Linguistics: Bilingual Encounters and Grammatical Outcomes. Oxford: Oxford University Press.

Ogechi, Nathan Oyori, 2002. Trilingual Codeswitching in Kenya -Evidence from Ekegusii, Kiswahili, English and Sheng. Dissertation zur Erlangung der Würde des Doktors der Philosophie der Universität Hamburg.

Hornby, A. S., 2005. Oxford Advanced Learner's Dictionary OF Current English. Oxford: Oxford University Press.

Payne, Thomas A., 1977. Describing Morphosyntax. Cambridge: University Press.

Pfaff, C., 1979. 'Constraints on Language Mixing: Intersentential Code-Switching and borrowing in Spanish and English', Language 155(2): 291-318.

Poplack, S., 1980. 'Sometimes I'll start a sentence in Spanish Y TERMINO EN ESPANOL: Toward a Typology of Code-Switching', Linguistics 18: 581-618.

Quirk, Randolph \& Greenbaum, Sidney, 1979. A University Grammar of English. Essex: ELBS/Longman.

Sankoff, D. and Poplack, S., 1981. 'A Formal Grammar for Code-Switching', Papers in Linguistics 14(1): 3-35.

Toribio, A. J., 2001. 'On the Emergency of Bilingual Code-Switching Competence', Bilingualism: Language and Cognition 4(3): 203-231.

Treffers-Daller, J., 1998. 'The IC Model and Code-Switching', Bilingualism: Language and Cognition 1: 98-99.

van Gelderen, E., 2010. An Introduction to the Grammar of English. Amsterdam/New York: John Benjamins.

van Gelderen, E. and MacSwan, J., 2008. 'Interface Conditions and Code-Switching: Pronouns, Lexical DPs, and Checking Theory', Lingua 118: 765-776.

Williams, Edwin, 1982. 'On the Notion of "Lexically Related" and a Head of a Word' Linguistic Inquiry, 12: 234-274. 